\title{
Muncipal Wastewater of Nag River Treatment By Membrane Bioreactor : A Simple System
}

\author{
Kiran D. Bhuyar ${ }^{1 *}$, Dr. V. S. Sapkal ${ }^{2}$, Dr. R. S. Sapkal ${ }^{3}$, Swapnil A. Dharaskar ${ }^{1}$, and Samir K. Deshmukh ${ }^{1}$
}

\begin{abstract}
An integrated laboratory-scale aerobic membrane bioreactor was used to treat municipal wastewater of Nag river at different HRTs from Nag river located at Nagpur city of India. The experiments were performed at hydraulic retention times from one day up to 15 days the performance of the reactor was evaluated based on the removal of organic matter COD, BOD, TDS and PH changes. The average COD, BOD, TDS removal efficiencies for wastewater were $90.50 \%, 81.90 \%, 91.95 \%$ respectively and $\mathrm{PH}$ changes from 4.5 to 7.6 on same HRTs. The relationship between the organic removal rate and HRT was found linear. The study demonstrated the influence of HRTs and suitability of MBR for treatment of Nag river wastewater.
\end{abstract}

Keywords - Nag river, MBR-Membrane Bioreactor, Municipal Wastewater Treatment, BOD, COD, TDS removal, etc.

\section{INTRODUCTION}

$\mathbf{I}_{v}^{\mathrm{N}}$ $\mathrm{N}$ recent years, different processes of purification of wastewater from various industrial or laboratory based processes has been of prime significance due to limited quantity of water available for direct use. Hence, maintaining the quality of drinking water is very essential to the public health. Although wastewater treatment is a common practice for supplying good quality of water from a source of water, the high price of purification, necessity of utilizing the waste products, and maintaining an adequate supply of good quality water have been the major issues. Municipal and industrial liquid/solid wastes differ mainly in their physical, chemical and biological characteristics. [3, 5, 7,14]. The Nag River, a tributary of the Kanhan River, flows in a serpentine path and is therefore named "Nag", the Marathi word for snake. And hence, the river and city is named as Nagpur.. While others says that the river flows through the old city of Nagpur and hence the city is named after this river. "Pur" is a common suffix given to cities, villages and towns across India, and is often simply translated "city" The seal of Nagpur Municipal Corporation depicts a cobra in the water of a river. The river wastewater is usually comprised of a high volume of greatly acidic matter which presents many disposal and treatment problems. Waste streams generally contain high levels of both dissolved organic and inorganic materials. The discharge of wastewaters is becoming increasingly restricted as pressures

\footnotetext{
${ }^{1 *}$ Assistant Professor, Department of Chemical Engineering, Priyadarshini Institute of Engineering \& Technology,Nagpur (M.S) India-440019

${ }^{2}$ Professor \& Head, Department of Chemical Technology, Sant Gadge Baba Amravati University, Amravati (M.S) India-444602:

${ }^{3}$ Professor, Department of Chemical Technology, Sant Gadge Baba Amravati University, Amravati (M.S) India-444602
}

from environmental regulations increase and as awareness of the negative impacts of seasonal discharges of water containing high nutrient and organic loadings into water courses spreads $[12,14]$.The objective of the present research was to enhance the Aerobic / anaerobic treatability of river wastewater effluent in MBR and was studied the influence of hydraulic retention time (HRT) on treatment operational parameters, COD, BOD, TDS and $\mathrm{pH}$ changes were investigated and good quality of effluent has been achieved.

\section{MAterials \& Methods}

TABLE I

CHARACTERISTICS OF THE MUNICIPAL WASTEWATER OF NAG RIVER

\begin{tabular}{|l|l|l|}
\hline Parameters & Value range & $\begin{array}{l}\text { Removal } \\
\text { Efficiency \% }\end{array}$ \\
\hline $\begin{array}{l}\text { Biological oxygen demand } \\
(\mathrm{BOD}), \mathrm{mg} / \mathrm{l}\end{array}$ & 15500 & $88.90 \%$ \\
\hline $\begin{array}{l}\text { Chemical oxygen demand } \\
(\mathrm{COD}), \mathrm{mg} / \mathrm{l}\end{array}$ & 23400 & $90.50 \%$ \\
\hline $\mathrm{pH}$ & $4.5-7.6$ & $40.78 \%$ \\
\hline $\begin{array}{l}\text { Total Dissolved Solids (TDS), } \\
\mathrm{mg} / \mathrm{l}\end{array}$ & 12200 & $91.95 \%$ \\
\hline Color & Greenish Black & \\
\hline
\end{tabular}

The reactor was operated at mesophillic temperature 25-40 ${ }^{0} \mathrm{C}$. The influent used for the experimental purpose was collected from nag river flowing from Sitabardi region located at Nagpur city. The influent COD concentration maintained constant, so that proper assistance of results can be done. The Wastewater at $\mathrm{pH} 6.5$ was fed into reactor. Different dilutions were prepared using distilled water. $\mathrm{pH}$ of influent was adjusted to 7-7.6, using a $6 \mathrm{M} \mathrm{NaOH}$ solution. Work was carried out using a constant COD of raw effluent changing the detention time and studied the COD, BOD, TDS removal by the reactor.

Seed Sludge: The initial inoculums for seed culture $900 \mathrm{ml}$ were the mixture of influent and mixed mesophilic sludge $\left(38^{\circ} \mathrm{C}\right)$ from the bed of an anaerobic digestion bioreactor which was obtained from the rural cow dung biogas plant near by Nagpur region. This is used as the inoculums in the Membrane Bioreactor. 
TABLE II

Classes Of Pressure Driven MEMbrane [10,14

\begin{tabular}{|l|l|l|l|}
\hline Process & $\begin{array}{l}\text { Driving } \\
\text { Force }\end{array}$ & di(nm) & Species Rejected \\
\hline $\begin{array}{l}\text { Microfiltration } \\
>50 \mathrm{~nm}\end{array}$ & $10-25 \mathrm{psi}$ & $\begin{array}{l}100- \\
20,000\end{array}$ & $\begin{array}{l}\text { TSS, Protozoa, } \\
\text { Bacteria, Viruses }\end{array}$ \\
\hline $\begin{array}{l}\text { Ultrafiltration } \\
2-50 \mathrm{~nm}\end{array}$ & $10-100 \mathrm{psi}$ & $2-10$ & $\begin{array}{l}\text { Macromolecules, } \\
\text { Colloids, Proteins }\end{array}$ \\
\hline $\begin{array}{l}\text { Nanofiltration } \\
<2 \mathrm{~nm}\end{array}$ & $\begin{array}{l}100- \\
500 \mathrm{psi}\end{array}$ & $0.5-2$ & $\begin{array}{l}\text { Small molecules, } \\
\text { Hardness, Viruses }\end{array}$ \\
\hline $\begin{array}{l}\text { Reverse Osmosis } \\
<2 \mathrm{~nm}\end{array}$ & $\begin{array}{l}100- \\
1500 \mathrm{psi}\end{array}$ & $0.3-0.5$ & $\begin{array}{l}\mathrm{NaCl}^{3-} \mathrm{Mg}^{2+}, \mathrm{Ca}^{2+}, \mathrm{SO}_{4}{ }^{2-} \\
\mathrm{NO}^{3-}, \mathrm{Color}^{-}\end{array}$ \\
\hline
\end{tabular}

\section{EXPERIMENTAL SET UP}

The experimental setup consists of feed waste tank, bioreactor, membrane module and an air tight container followed by a vacuum pump. The reactor was operated at mesophillic temperature $30-40{ }^{\circ} \mathrm{C}$. The schematic diagram of the lab-scale Membrane bioreactor is as shown in fig. 1 . The bioreactor is made up of cylindrical still vessel placed vertically, so that minimum floor area is required. The reactor has an internal diameter of $15.2 \mathrm{~cm}$ with a height of $90 \mathrm{~cm}$. An $10 \mathrm{~L}$ reactor was used for the experiment, out of which $1.5 \mathrm{~L}$ volume occupied by packing material. Thus remaining volume of the bioreactor was available for the liquid phase. The total volume of the reactor $15 \mathrm{~L}$ was used. In the pilot trial, the activated sludge is pumped along the membrane surface at high velocity ensuring adequate turbulence thereby minimizing membrane fouling and enhancing cleaning efficiency. The permeate is removed from the activated sludge through the membrane wall, which provides an absolute barrier, producing an MBR permeate free from bacteria and suspended solids.

\section{Analytical Methods:}

The sample was poured in the beaker and electrode dipped in it to read the $\mathrm{pH}$ of the sample. Total dissolved solids(TDS) etc all remaining parameters are measured by following standard methods, 2540B, 2540D, 2540E respectively.

Open reflux method was followed for the determination of COD of the sample. $\mathrm{pH}$ was measured by using the electronic digital $\mathrm{pH}$ meter which gives the value of $\mathrm{pH}$ of the sample directly. $(7,14)$

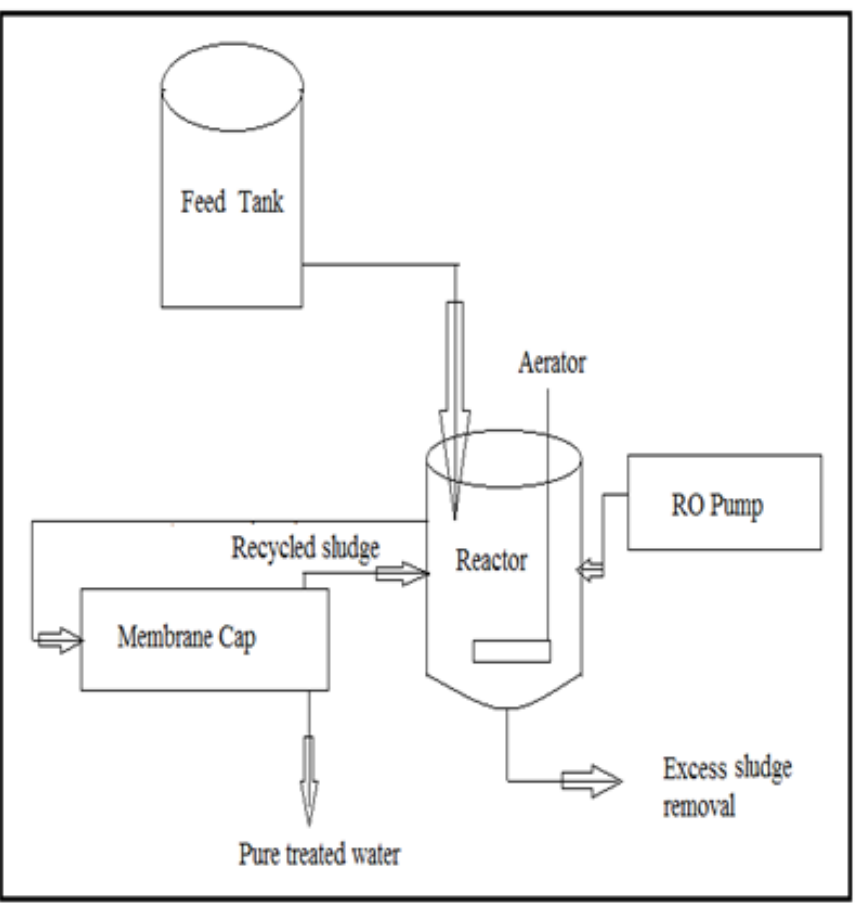

Fig. 1 Schematic diagram of the Membrane Bioreactor used to treat municipal wastewater of Nag river.

TABLE III

EXPERIMENTAL RESULTS OBTAINED IN MBR SYSTEM FOR MUNCIPAL WASTEWATER OF NAG RIVER TREATMENT AT DIFFERENT STAGES.

\begin{tabular}{|c|c|c|c|c|c|c|}
\hline Stages & $\begin{array}{c}\text { DO } \\
(\mathbf{m g} / \mathbf{l} \\
)\end{array}$ & $\begin{array}{c}\text { COD } \\
(\mathbf{m g} / \mathbf{l})\end{array}$ & $\begin{array}{c}\mathbf{B O D} \\
(\mathbf{m g} / \mathbf{l} \\
)\end{array}$ & $\begin{array}{c}\text { TDS } \\
(\mathbf{m g} / \mathbf{l})\end{array}$ & $\mathbf{p H}$ & Color \\
\hline Initial & 0 & 23400 & $\begin{array}{c}1550 \\
0\end{array}$ & 12200 & 4.5 & $\begin{array}{c}\text { Greenish } \\
\text { black }\end{array}$ \\
\hline Pretreatment & 0 & 15800 & 9800 & 8400 & 7.6 & Colorless \\
\hline $\begin{array}{c}50 \% \text { Dilution } \\
\text { (Influent) } \\
\text { (Day -0) }\end{array}$ & 2.8 & 7900 & $\begin{array}{c}1010 \\
0\end{array}$ & 4200 & 7.6 & Colorless \\
\hline Day -5 & 3.7 & 3800 & 5500 & 2450 & 7.6 & Colorless \\
\hline Day -10 & 4.9 & 1100 & 1850 & 1100 & 7.4 & colorless \\
\hline $\begin{array}{c}\text { Day -15 } \\
\text { (Effluent) }\end{array}$ & 6.2 & 750 & 1120 & 338 & 7.3 & colorless \\
\hline
\end{tabular}

\section{PROCEDURE}

As discussed earlier, the experimental setup consists of a waste container, membrane module and an air tight container followed by a vacuum pump. Firstly, the reactor is tested by noting its COD, DO, BOD, TDS values as the initial ones. The stillage after being tested is made more basic by the addition of $1 \mathrm{~N} \mathrm{NaOH}$.

Now the wastewater is again tested by noting its COD, DO, BOD, TDS values, which are found to be lower than the initial ones, along with the noticeable removal of color. The stillage is now diluted with $50 \%$ water by volume. There is a further drop in all parameters.

The wastewater is now fed into the reactor, with the membrane module submerged in it. Into the reactor, 1.08 liter of bacteria, provided by the industry itself, was added (as $108 \mathrm{ml}$ of solution is enough to for the digestion of 1liter of 
wastewater). The wastewater is then passed through the set of membranes, placed in the RO membrane module thus purifying the water to a large extent. The clear treated water is then collected in an air tight container, to maintain all parameters and keep it constant. This process of collecting clear water from the container of wastewater (containing membrane module), to the air tight container, is processed with a vacuum pump. The MBR permeate is discharged directly to the local burn (water course) without the need for any further treatment.

\section{Results \& Discussion}

Fig.-2- COD reduction is of prime importance while treating the wastewater. Its value reduced drastically as shown in the fig.1. The reduction was marginal during the first five days; however, it was exponential after $5^{\text {th }}$ day. The overall efficiency after the treatment was found to be $90.50 \%$. Yamini et al (2008) also showed similar reductions in the value of COD while treating the waste with MBR equipped with mesh filter [22]. However, the nature of graph varied to a large extent for Shoutong Zhang et al (2005) when they did similar treatment, but at comparatively higher temperatures.

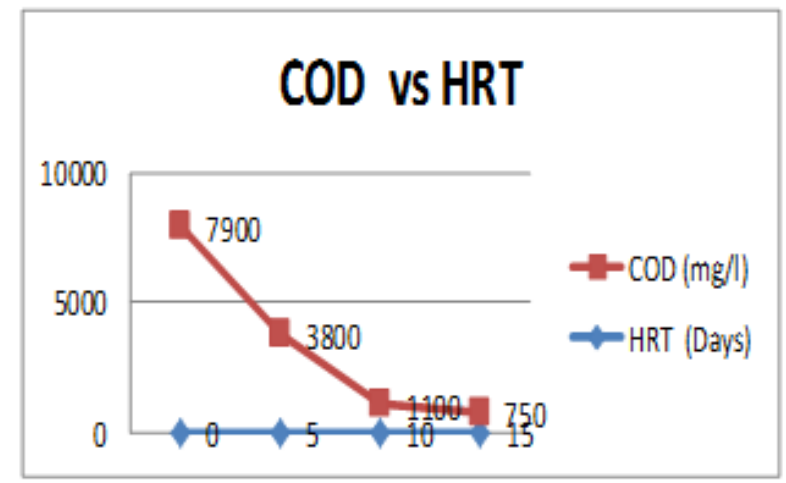

Fig. 2 Influence of HRT on COD Removal Efficiency

Fig,-3- indicates that the removal of BOD cannot be completely eliminated. Rather, a certain value remains, no matter what treatment is enforced upon the waste. The variation of BOD with the hydraulic retention time was found to be as shown in the above graph. In the first five days, the reduction of BOD was drastically lowered, however, during the next ten days, it was moderate. The overall efficiency of removal of BOD was found to be $81.90 \%$. Higher efficiencies were obtained by other scientists due to MBRs constituting of various efficient membrane modules [11].

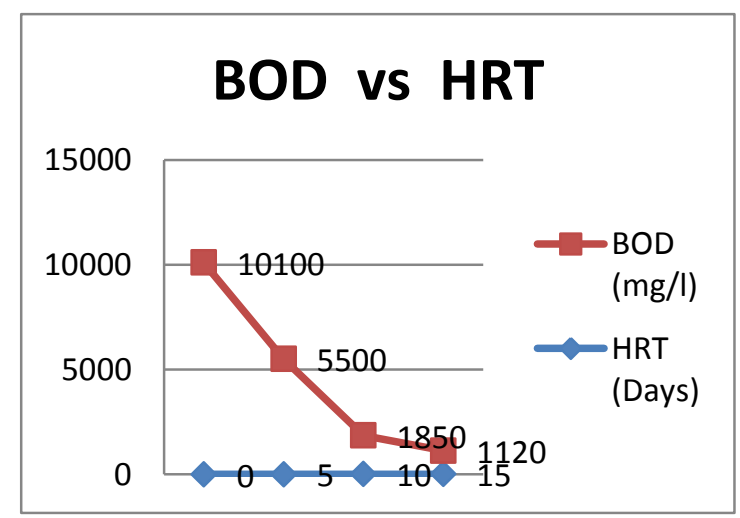

Fig. 3 Influence of HRT on BOD Removal Efficiency

Fig.-4- shows that the TDS removal is as essential as the removal of COD or BOD. Consistent treatment with MBR showed high reduction in the values of TDS. When the sample was treated for low retention time, the removal of dissolved solids was found minimum. However, as the retention time was increased, the efficiency increased exponentially. After a particular reduction was achieved, the retention time showed no effect on the removal of TDS. The final efficiency of TDS was found to be $91.95 \%$. Various studies based on the removal of TDS showed similar results.

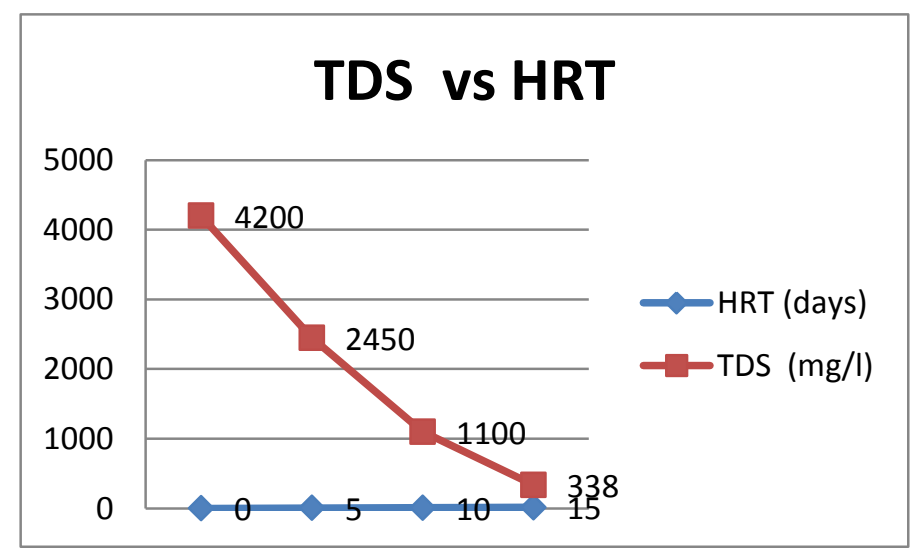

Fig-.4 : Influence of HRT on TDS Removal Efficiency

Fig.-5- represents the initial value of $\mathrm{pH}$ was found to be 4.6, when bought from the wastewater. However, due to difficulties in treating acidic solutions using membrane technologies (for the fear of damage of membranes), the waste was made basic by the addition of $1 \mathrm{~N} \mathrm{NaOH}$. The $\mathrm{pH}$ was brought to a value of 7.6, and maintained constant for efficient and easy treatment of the waste. Comparison with the work of others showed that the addition of base was essential in order to obtain efficient treatment. 




Fig. 5 Influence of HRT on $\mathrm{pH}$

\section{CONCLUSION}

1. This work is mainly focused on the treatment of municipal nag river wastewater, obtained from sitabardi region of Nagpur city, using a Membrane Bioreactor with RO process. The work involved pretreatment with activated charcoal sand filter followed by dilution, at $25-35^{\circ} \mathrm{C}$. The waste was then fed to the membrane bioreactor, equipped with a nylon 6,6 membrane with a $0.2 \mu \mathrm{m}$ pore size, where biological substances were added in order to facilitate digestion of the waste. The following conclusions can be drawn from this study

2. The bioreactor is able to display an efficiency of $70.50 \%, 81.90 \%$ and $91.95 \%$ for the reduction of COD, BOD and TDS efficiently. The Total Suspended Solids is nil after pretreatment hence not included as part of assessment. The color of solution changes from dark brown to colorless when treated with activated charcoal. Also, the $\mathrm{pH}$ of the solution changes from 4.5 to 7.6, after the addition of $\mathrm{NaOH}$.

3. The main advantage of this work is that, the MBR technology has proven optimal for treatment of such kind of river municipal wastewaters. The entire process is found to be cost effective, as the overall cost of the set-up is marginally less, as compared to the conventional set-ups used, for similar efficiencies.

4. Hence it may be conclude that, this method, if given more time for research, could give substantial improvements without much increase in the cost.

\section{ACKNOWLEDGEMENT}

The authors gratefully acknowledge to Research Lab., Chemical Engineering Department, V.N.I.T \& P.I.E.T., R.T.M.N.U. Nagpur, for providing all necessary facilities to carry out quality of work.

\section{REFERENCES}

[1] Esquivel, F. M. et al, (2008) "Performance of a packed reactor with opuntia imbricate for municipal wastewater treatment", Environmental Research Journal 2, 238-245

[2] Brindle, K. \& Stephenson, T. (1996) "The applications of membrane biological reactors for the treatment of wastewater", Biotechnology, 49: 601-610.

http://dx.doi.org/10.1002/(sici)1097-0290(19960320)49:6<601::aid-

bit1>3.0.co;2-s
[3] Demirel, B. et al, (2005) "Anaerobic Treatment of Dairy Wastewaters: A review”, Process Biochemistry Elsevier, $40: 2583-2595$, (2005). http://dx.doi.org/10.1016/j.procbio.2004.12.015

[4] Cicek, N., Macomber J., Davel J., Suidan, M.T Audic J. \&Genester, P, (2001), "Effect of solids retentions time on the performance and biological characteristics of a membrane bioreactor", Water SciTechnol 43, 43-50

[5] D. Jeison (2007), "Anaerobic membrane bioreactor for wastewater treatment: feasibility and potential applications.

[6] Geoffrey S. Simate, John Cluett, Sunny E. Iyuke, Evans T. Musapatika, SehliseloNdlovuLubina F. Walubita, Allex E. Alvarez (2011). "The treatment of bewery wastewater for reuse: State of the art", Desalination 273, 235-247 http://dx.doi.org/10.1016/j.desal.2011.02.035

[7] APHA-AWWA-WPCF, "Standard methods for the examination of water and wastewater" 18th Ed. Washington DC. American Health Association, American water works association and water pollution control federation, 10-137, (1992).

[8] Kalyuzhnyi, Galdchenko, M., Starostina, E., Shcherbakao, S and Versprille, A. (2005). "Combined biological and physio-chemical treatment of baker's yeast waste water", Water Science Technology, Volume 52, pp. 175-1881

[9] M. Seneviratne (2007), "A pratical approach to water conservation for commercial and industrial facilities", Elservier, Oxford.

[10] PawarAvinashShivajirao(2009). "Treatment of Distillery Wastewater using Membrane Technologies", Interational Journal of Advance Engineering and Studies, E-ISS2249-8974.

[11] Smith, C.W., Di Gregorio, D. \&Talcot, R.M., (1969), "The use of ultrafication membrane for activated sludge separation", purdue industrial waste, pp.1300-1310

[12] V.K. Gupta, Suhas (2009), "Application of low -cost adsorbents for dye removal", Journal of Enivronment management 90(8), 2313-2342 http://dx.doi.org/10.1016/j.jenvman.2008.11.017

[13] X.L. Melamane, P.J Strong and J.E Burgess (2006), "Treatment of wine distillery wastewater", A review with Emphasis on Anaerobic Membrane Reactors.

[14] Metcalf and Eddy, Inc. Revised by George Tchobanologous, (2007)."Wastewater Engineering: Treatment, Disposal, Reuse", McGraw Hill Book Company ,2nd Edition, 1507-1530, 